\title{
First-year pharmacy students' prior knowledge correlates with study progress and reveals different dynamics of misconceptions
}

\author{
ILONA SÖDERVIK ${ }^{1,2^{*}}$ https://orcid.org/0000-0001-8575-487X
}

LEENA HANSKI ${ }^{3}$ https://orcid.org/0000-0002-3121-8542

NINA KATAJAVUORI ${ }^{1}$ https://orcid.org/0000-0001-5093-2402

${ }^{1}$ Centre for University Teaching and Learning, University of Helsinki, Helsinki, Finland

${ }^{2}$ Department of Teacher Education, University of Turku, Finland

${ }^{3}$ Division of Pharmaceutical Biosciences, Faculty of Pharmacy, University of Helsinki, Finland

\begin{abstract}
The varying levels and quality of students' prior knowledge pose a challenge for instruction at university. Due to the scarcity of studies in pharmacy, in this study pharmacy students $(\mathrm{N}=126)$ prior knowledge of biosciences was measured at the beginning of their first study year using a questionnaire comprising ten multiple choice questions and a case task. The results of multiple-choice and open-ended questions revealed serious gaps and different-level misconceptions in students' answers partly related to the absence of elementary knowledge. The level of prior knowledge correlated with study progress measured at the end of the first study year. The study's findings suggest that it is possible to identify students at risk of delayed studies using this kind of relatively light pre-test. Problem-solving tasks such as case descriptions can be used to detect potential misconceptions. The pedagogical implications of these results are discussed.
\end{abstract}

Keywords: Misconceptions, Conceptual Change, Antibiotic Resistance, Life Science Education, Higher Education

\section{Introduction}

The challenge in healthcare education, including pharmacy, is that scientific knowledge is growing faster than ever before and new content needs to be included into an already crowded curriculum. At the same time, students enter higher education with great variations in the level and quality of their prior knowledge. The above mentioned aspects pose a huge challenge for curriculum planners and educators, but above all, for the students who struggle to reach a high level of professional expertise at university.

Pharmacy is a multidisciplinary field involving natural sciences, health sciences and social sciences. After graduating, pharmaceutical experts can work in a range of positions from drug development to official duties in the pharmaceutical sector and patient-centred duties in pharmacies and hospitals. Often pharmacists act as mediators or even filters between patients, drug research and information obtained from the media or lay persons.

A deep understanding of relevant natural science phenomena forms the basis for the professional expertise needed to provide accurate information and advice for customers, who might have inadequate perceptions and beliefs related to medication. In Finland, a significant proportion of pharmacy students graduate and shift to the work force as pharmacists with a bachelor level degree. Hence, it is crucial to make sure that after three years at university, pharmacy students gain an adequate understanding related to central natural science phenomena.

\section{Different roles of prior knowledge}

Research has conclusively shown that university students come to science lessons loaded with expectations, previous knowledge and prior conceptions that in some cases significantly contradict the scientific view (Carey, 1985; Chinn \& Brewer, 1993; Vosniadou, 1994; Limón, 2001; Mason, 2001; Duit \& Treagust, 2003; Kendeou, \& Ioannides, 2003; Vosniadou \& Skopeliti, 2005; Broughton, Sinatra, \& Nussbaum, 2013; Diakidoy, 2013; Södervik, Mikkilä-Erdmann \& Chi, 2019; Södervik et al., 2017). Previous studies have shown that

${ }^{*}$ Correspondence: Ilona Södervik, Centre for University Teaching and Learning, University of Helsinki, Siltavuorenpenger 1A, FI-00170 University of Helsinki, Finland. Tel: +35850317 5495. E-mail: ilona.sodervik@helsinki.fi 
the level and quality of medical students' prior knowledge varied remarkably related to elementary matters such as the anatomy of the human heart and circulatory system and different level misconceptions existed (Södervik, Mikkilä-Erdmann \& Chi, 2019). Worryingly, challenges in conceptual understanding were related to weaker success in subsequent more complex problem-solving situations such as in clinical reasoning.

Additionally, although the role of prior knowledge in conceptual learning is well known in general, there is still relatively little knowledge about domain-specific conceptual learning in higher education (Boshuizen \& Schmidt, 2008; Flaig et al., 2018; Södervik, MikkiläErdmann \& Chi, 2019). This is the case although increasing evidence exists that learning is domainspecific, meaning that there are discipline-specific characteristics that should be considered when designing instruction, and learning complex content also poses serious challenges for university students (Södervik, Mikkilä-Erdmann \& Chi, 2019).

The quality of university students' pre-instructional conceptions plays a critical role in learning (Bransford, Brown \& Cocking, 2000). According to previous studies, the main barrier to learning is often not what the student's knowledge structures lack, but what the student has, namely, alternative conceptual frameworks (Carey, 2000). Therefore, students' prior conceptions relating to a topic to be learned may not always facilitate learning but might lead to systematic misinterpretations. Therefore, reaching a scientific understanding often means recognising one's existing knowledge structures and sometimes even abandoning certain existing conceptions - a process that usually happens gradually and suggests intentional learning and teaching (e.g., Chi \& Roscoe, 2002; Sinatra \& Pintrich, 2003). This kind of learning is described using the theories of conceptual change (Posner et al., 1982; Chi, 1992; Vosniadou, 1994; Limón \& Mason, 2002).

The research tradition of conceptual change became a focus of learning in the 1970s and has lately become one of the leading paradigms in the research on science teaching and learning (Posner et al., 1982; Treagust \& Duit, 2008). The term 'conceptual change' refers to the idea that learning is not only about acquiring new information and piling fact upon fact but about recognising that existing knowledge structures often must change fundamentally in order to reach scientific understanding (diSessa, 1993).

Reaching conceptual change poses a challenge to learners since robust naïve knowledge structures may provide seemingly explanatory power in everyday life, but often they hinder or even prevent the higher-level cognitive processing needed in problem-solving tasks in adverse and varying circumstances. Therefore, prior knowledge that is prerequisite for all conceptual learning, has a dual role in the learning process: it may either ease learning when it is in unison with the new knowledge to be learned, or it may hinder or even prevent learning if there are discrepancies between new knowledge and one's previous conceptions (Vosniadou, 2013). This paradox of learning (Sinatra \& Mason, 2013) also poses a challenge for learning and instruction in higher education. Nevertheless, conceptual change research in higher education has almost been neglected until recently.

\section{Misconceptions as barriers for systemic understanding in pharmacy}

Misconception can be defined as a conception that is not in unison with current scientific understanding. Often these robust misconceptions remain unnoticed both by the teachers and students themselves, hindering understanding of complex scientific phenomena and professional development. Typically, the teachers utilise multiple-choice questionnaires to measure the students' level of prior knowledge. However, multiple-choice questions (MCQs) often do not reveal students' misconceptions effectively. Therefore, in this study, a range of tasks were utilised in order to detect students with alternative conceptions in the early stages of studies.

According to Chi (2008), knowledge can be misconceived at three levels of complexity, including false beliefs, mental models, and ontological categories (Chi, 2008). The most basic level of misconception is the false belief, which is a single incorrect idea that can usually be stated in a single proposition (Chi, 2013). False beliefs concern factual-level misconceptions. When knowledge is misconceived at the false-belief level, students have one or more incorrect individual beliefs about certain content that they are about to learn. False beliefs are thought to be relatively easy to rectify because they do not require radical restructuring of a mental model but rather a belief revision (Chi, 2008).

The next level of misconceptions according to Chi (2008) is that of flawed mental models. It consists of multiple propositions and features as well as interrelationships between those features. Some of these relations are not represented explicitly as propositions and may be inferred from the features of the model. Thus, mental models are not simply a collection of individual beliefs, but because they possess complex interrelationships between propositions, they have a cohesive integrated structure (Chi, 2013). In science education, the complex and multifaceted nature of most scientific concepts requires a systemic understanding of how separate concepts and facts combine to form a complex network (Mayr, 1997; Barak, Sheva, \& Gorodetsky, 1999; Verhoeff, Waarlo, \& Boersma, 2008). Misconceptions in general are a serious problem for health sciences education, because the systemic nature of much content means that a single misconception can have repercussions on the conceptions of other interrelated aspects (Chi, Chiu, \& deLeeuw, 1991). Because of this, even though a student may possess several correct individual beliefs about a scientific phenomenon, he or she may still have a flawed mental model. The importance of systemic understanding in learning science has become unquestioned among science education researchers over the past decade (Branstädter, Harms, \& Großschedl, 2012). However, 
science instruction in the school curriculum has been criticised because biological processes are often reduced to separate facts instead of being looked at as systemic wholes (Barak et al., 1999; Plate, 2010). Therefore, there is a high risk that science learning remains as fragmented and unrelated facts. Conceptual change at the level of mental models can be called mental model transformation.

The third and most complex level of misconceived prior knowledge according to Chi (2008) is the ontological level, where conceptual change requires a category shift. Misconceptions at this level occur when students misattribute a scientific phenomenon to one category versus another (Chi, 1997; 2005). This means that if students' prior conceptions belong to one branch of ontological category and correct conceptions belong to another branch, they conflict by definition of kind or ontology, and therefore conceptual change requires a shift across ontological categories.

\section{The study}

Although the role of prior knowledge is well understood among learning researchers in general, there is still relatively little knowledge about domain-specific conceptual learning in higher education, and studies in pharmacy education are especially scarce. Therefore, the purpose of this study is to investigate first-year pharmacy students' level and quality of prior knowledge related to basics of biosciences within a level that should be mastered after completing Finnish high school studies. In addition, pharmacy students' reasoning skills related to a patient case is studied to gain understanding of pharmacy students' possible misconceptions and challenges related to problem solving.

Thus, the research questions in this study are: (1) What is the first-year pharmacy students' initial level and quality of prior knowledge related to biochemistry, cell biology and molecular biology measured via MCQs? (; (2) How successfully do the students recognise the phenomenon, identify and define the relevant concepts and explain the pathophysiology related to a case task concerning antibiotic resistance?; (3) How many students have misconceptions of the scientific model concerning the antibiotic resistance?; (4) How is the students' level of prior knowledge (as measured with MCQs) related to their success in patient case task, course grade and study progress during the first study year?

\section{Methods \\ Participants}

A cohort of first-year pharmacy students $(\mathrm{N}=126)$ participated in the study during 2018-2019. Only students with no prior study experience in pharmacy were included in the study. A total of $98(77.8 \%)$ of the participants were women, $26(20.6 \%)$ were men and two $(1.6 \%)$ were other. The sample can be called representative, since the particular cohort consists of 158 students (women $\mathrm{n}=116,73,4 \%$; men $\mathrm{n}=42,26,6 \%$ ). Participation was voluntary and informed consent was obtained.

\section{Materials and procedure}

The measure consisted of background questions, such as gender and the year the study of pharmacy commenced, ten MCQs with the one-right/three-wrong answer model and a case task with two open-ended questions. MCQs tested the level of basic knowledge of biochemistry, cell biology and molecular biology. The tasks were designed at a level that should have been mastered by the time Finnish high school studies were completed. Students' course grades and number of credits at the end of the first study year were utilised as background variables.

\section{Figure 1: Case task concerning antibiotic resistance}

A patient enters a pharmacy to pick up the broad-spectrum antibiotic which was prescribed for him. The patient tells you that this is the second antibiotic prescribed to him because the inflammation-relieving action of first antibiotic was not achieved. In fact, the symptoms got worse. The patient seems not to be complying with the medication and tells you that he has heard several news items about the injurious side-effects of antibiotics, especially their impact on intestinal bacteria. You suggest that the patient could have registered probiotics to be used with the antibiotics. Probiotics are used for example to prevent and cure antibiotic diarrhoea.

A) Name and define the essential science concepts which are related to this case (2 - 4 concepts)

B) Describe the mechanisms related to this scientific phenomenon - from the perspective of both the human and the microbe

The case task was a 63 -word long description of a patient encounter handling antibiotics and antibiotic resistance (Figure 1). The topic was chosen because resistance to antibiotics is a globally-growing problem that presents real threats to public health and costs due to failure in the treatment and prevention of infectious diseases (WHO, 2015) and it was anticipated that the topic would already be familiar to the students at the start of university. Antibiotics are commonly used to treat a range of diseases and pharmacy students counsel these patients regularly. Thus, a comprehensive understanding of the safe use of antibiotics and their biomedical mechanisms is necessary for patient counselling. Additionally, in Finland, students typically have their first patient encounters during their first internship period in the second study year and it is therefore important to model these encounters via instruction at the early stages of studies. Furthermore, the use of written case tasks has been shown to support learning well especially at the early stages of study, when students have to do a great 
deal of reasoning related to conceptual knowledge and hands-on problems or patient encounters can still be overwhelming (Boshuizen et al., 2012).

Students gave their answers individually in a Moodle electronic exam environment in a lecture hall and they had 40 minutes to complete both the MCQs and the case task. Students were permitted to leave questions unanswered.

\section{Analyses}

Related to the MCQs, descriptive statistics such as frequencies of right and most typical false answers as well as the sum scores for correct answers, were calculated. Question A from the case task was scored by identifying and defining relevant concepts for the case (one score for each concept/definition, with a maximum of eight points), and Question B based on the level and quality of the explanation of the underlying life sciencerelated phenomena (maximum eight points). The analysis related to the dynamics of misconceptions in the openended questions was conducted using a directed content analysis approach in which codes of analysis are derived from theory before and during data analysis (Hsieh \& Shannon, 2005). Misconceptions were classified following the theoretical model of Chi (2008). However, the authors differentiated between four rather than three categories related to misconceptions by forming categories of false beliefs, factual misconceptions, misconceptions at the mental model level, and misconceptions at the ontology level.

Table I: Multiple-choice question answers

\begin{tabular}{|c|c|c|c|c|c|}
\hline & $\begin{array}{l}\text { Correct } \\
\text { answer } \\
(\% \text { of } \\
\text { students })\end{array}$ & $\begin{array}{l}\text { Most common } \\
\text { wrong answer } \\
\text { (\% of students) }\end{array}$ & $\begin{array}{l}\text { The second most } \\
\text { common wrong } \\
\text { answer } \\
\text { (\% of students) }\end{array}$ & $\begin{array}{l}\text { The third most } \\
\text { common wrong } \\
\text { answer } \\
\text { (\% of students) }\end{array}$ & $\begin{array}{l}\text { Missing } \\
\text { (\% of } \\
\text { students) }\end{array}$ \\
\hline $\begin{array}{l}\text { 1. A DNA sequence responsible for } \\
\text { encoding a certain protein is called a }\end{array}$ & $\begin{array}{c}\text { gene } \\
(78.6)\end{array}$ & $\begin{array}{l}\text { genome } \\
(11.1)\end{array}$ & $\begin{array}{l}\text { chromosome } \\
(7.1)\end{array}$ & $\begin{array}{c}\text { chromatin } \\
\text { (3.2) }\end{array}$ & $(0.0)$ \\
\hline $\begin{array}{l}\text { 2. Typical molecular weights of protein } \\
\text { molecules are in the range of }\end{array}$ & $\begin{array}{l}10-100 \mathrm{kDa} \\
(28,6)\end{array}$ & $\begin{array}{l}10-100 \mathrm{Da} \\
(30,2)\end{array}$ & $\begin{array}{l}100 \mathrm{Da}-1 \mathrm{kDa} \\
(25,4)\end{array}$ & $\begin{array}{c}>1000 \mathrm{kDa} \\
(9,5)\end{array}$ & $(6,3)$ \\
\hline $\begin{array}{l}\text { 3. Which of the following is not a } \\
\text { biopolymer (a biological } \\
\text { macromolecule)? }\end{array}$ & $\begin{array}{c}\text { phospholipid } \\
(37,3)\end{array}$ & $\begin{array}{c}\text { glycogen } \\
(30,2)\end{array}$ & $\begin{array}{l}\text { Ribonucleic acid, } \\
\text { RNA } \\
(15,9)\end{array}$ & $\begin{array}{c}\text { protein } \\
(15,1)\end{array}$ & $(1,6)$ \\
\hline $\begin{array}{l}\text { 4. Transcription is a biological process in } \\
\text { which }\end{array}$ & $\begin{array}{l}\text { A DNA strand } \\
\text { is applied to } \\
\text { produce a } \\
\text { strand of RNA } \\
(69,8)\end{array}$ & $\begin{array}{l}\text { A strand of RNA } \\
\text { is applied to } \\
\text { produce an amino } \\
\text { acid sequence } \\
\quad(15,1)\end{array}$ & $\begin{array}{l}\text { A strand of RNA } \\
\text { is applied to } \\
\text { produce a strand } \\
\text { of DNA } \\
(10,3)\end{array}$ & $\begin{array}{l}\text { A strand of DNA } \\
\text { is copied to yield } \\
\text { a new strand of } \\
\text { DNA } \\
(4,0)\end{array}$ & $(0,8)$ \\
\hline $\begin{array}{l}\text { 5. When a cell secretes mediators in order } \\
\text { to affect other cells nearby, the } \\
\text { phenomenon is called }\end{array}$ & $\begin{array}{l}\text { Paracrinic } \\
\text { signalling } \\
(38,1)\end{array}$ & $\begin{array}{l}\text { Endocrinic } \\
\text { signalling } \\
(42,1)\end{array}$ & $\begin{array}{l}\text { Autocrinic } \\
\text { signalling } \\
(15,1)\end{array}$ & $\begin{array}{l}\text { Juxtacrinic } \\
\text { signalling } \\
(4,0)\end{array}$ & $(0,8)$ \\
\hline $\begin{array}{l}\text { 6. Within different tissues and organs, } \\
\text { human cells differ from each other in } \\
\text { terms of morphology and function. } \\
\text { Why? }\end{array}$ & $\begin{array}{l}\text { The cells } \\
\text { express } \\
\text { differential } \\
\text { genes } \\
(62,7)\end{array}$ & $\begin{array}{l}\text { One gene may } \\
\text { yield various } \\
\text { different proteins } \\
\text { depending on the } \\
\text { cell type } \\
(26,2)\end{array}$ & $\begin{array}{c}\text { The genetic } \\
\text { material is } \\
\text { different between } \\
\text { the cells } \\
(8,7)\end{array}$ & $\begin{array}{l}\text { Proteins are } \\
\text { folded } \\
\text { differentially } \\
\text { depending on } \\
\text { cell type } \\
(2,4)\end{array}$ & $(0,0)$ \\
\hline $\begin{array}{l}\text { 7. A tissue that is localized on the outer } \\
\text { surfaces of the body and involves tight } \\
\text { junctions between cells is called }\end{array}$ & $\begin{array}{l}\text { epithelium } \\
(66,7)\end{array}$ & $\begin{array}{c}\text { Connective tissue } \\
(24,6)\end{array}$ & $\begin{array}{l}\text { pericardium } \\
(6,3)\end{array}$ & $\begin{array}{c}\text { Stranded muscle } \\
\text { tissue } \\
(2,4)\end{array}$ & $(0,0)$ \\
\hline $\begin{array}{l}\text { 8. Enzymes are biocatalysts that are } \\
\text { crucial to living organisms. Which of } \\
\text { the following concepts is related to } \\
\text { enzyme catalysis? }\end{array}$ & $\begin{array}{c}\text { Transition state } \\
(34,1)\end{array}$ & $\begin{array}{l}\text { coagulation } \\
\quad(33,3)\end{array}$ & $\begin{array}{l}\text { translation } \\
(20,6)\end{array}$ & $\begin{array}{l}\text { resonance } \\
(9,5)\end{array}$ & $(2,4)$ \\
\hline $\begin{array}{l}\text { 9. Which of the following molecules can } \\
\text { penetrate a phospholipid bilayer? }\end{array}$ & $\begin{array}{l}\text { Carbon } \\
\text { dioxide } \\
(51,6)\end{array}$ & $\begin{array}{c}\text { Adenosine } \\
\text { triphosphate } \\
(\text { ATP) } \\
(20,6)\end{array}$ & $\begin{array}{l}\text { glucose } \\
(14,3)\end{array}$ & $\begin{array}{c}\text { arginin-amino } \\
\text { acid } \\
\text { (see the picture) } \\
(12,7)\end{array}$ & $(0,8)$ \\
\hline $\begin{array}{l}\text { 10.The citric acid cycle involves a } \\
\text { sequence of metabolic reactions that }\end{array}$ & $\begin{array}{c}\text { Produce } \\
\text { carbon dioxide } \\
(32,5)\end{array}$ & $\begin{array}{c}\text { Produce most of } \\
\text { the ATP } \\
\text { consumed by the } \\
\text { cell } \\
(38,9)\end{array}$ & $\begin{array}{c}\text { Breaks down } \\
\text { glucose and fatty } \\
\text { acids in } \\
\text { mitochondria } \\
(18,3)\end{array}$ & $\begin{array}{c}\text { Consumes } \\
\text { molecular } \\
\text { oxygen } \\
(9,5)\end{array}$ & $(0,8)$ \\
\hline
\end{tabular}


False beliefs were misconceptions related to wordings (such as "flora" when referring to microbiota), whereas factual misconceptions might have more serious consequences for systemic understanding. Factual misconceptions referred to the use of erroneous concepts such as considering probiotics to be a synonym for lactic acid bacteria. Mental model misconceptions referred to challenges in systemic level understanding and this category included answers in which antibiotic resistance was explained using concepts of immunology indicating that the participant did not understand the pathophysiology of the phenomenon of antibiotic resistance. Ontology level misconceptions were fundamental misconceptions indicating challenges in understanding the nature of pharmacy as a multidisciplinary subject. In these answers, the participant had to explain a life science phenomenon with human behaviour or treatment practice.

The answers to the case task were analysed by three researchers, one of whom was a biologist and two who were experts in pharmacy. An inter-rater analysis was accomplished with $15 \%$ of the data, and Cronbach's $\alpha$ value of reliability was found to be 0.917 for the scoring of Question A and 0.946 for the scoring of Question B. Statistical analyses, such as chi-square $\left(\chi^{2}\right)$ tests, Pearson's correlation tests and individual samples $t$-tests, were accomplished using SPSS Statistics 24 (IBM, Armonk, NY).

\section{Results}

First-year pharmacy students' level and quality of prior knowledge related to biochemistry, cell biology and molecular biology

The students received approximately 5.0 scores out of 10 $(\max =9.0 ; \min =1.0 ; \mathrm{SD}=2.11)$ from the MCQs measuring basic knowledge of biochemistry, cell biology and molecular biology, within a level that should be mastered after completing Finnish high school studies. The proportion of correct answers did not exceed $80 \%$ even for the most elementary questions concerning the concept of the gene and transcription process, revealing lack of knowledge and serious misinterpretations in students' prior knowledge (Table I).

The most challenging MCQ for the students seemed to be related to the typical molecular weight of protein molecules and the citric acid cycle. The highest proportion of correct answers was related to elementary level understanding related to the concept of the gene (item number one) and process of transcription (item number four), but even in those, about $20 \%$ of the participants gave an incorrect answer.

\section{Case task concerning antibiotics and antibiotic resistance}

Results related to the case task answers revealed that 101 students (out of 126) had answered the case task. In general, students were able to identify and explain on average 2.29 correct concepts $(\min =0.0 ; \max =8.0$; $\mathrm{SD}=1.87$ ) related to the phenomenon (open task: Question A). The variation in scores among students was rather high. When investigating the results related to the question measuring understanding, the mechanisms of the life science phenomena of the described situation (open task: Question B), the students received relatively low scores (mean $=0.79 ; \min =0.00 ; \max =3.0 ; \mathrm{SD}=0.79$ ).

A closer look at the case task revealed that only $42 \%$ of students were able to recognise the phenomenon of antibiotic resistance within the case task. Those students had also received significantly higher scores from the MCQs measuring basic level of prior knowledge related to biochemistry, cell biology and molecular biology $(t(99)=-2.455 ; p=0.016)$.

\section{Misconceptions related to the case task}

A total of 28 students ( $28 \%$ of those who had answered the case task) had one or several misconceptions either related to the concepts (case task: Question A) or related to the pathophysiology of the case (case task: Question B). The most typical misconceptions in the case task are presented in Table II.

Table II: Different-level misconceptions in students' case task answers

\begin{tabular}{llc}
\hline Category & Description & Frequency \\
\hline $\begin{array}{l}\text { Ontological } \\
\text { misconceptions }\end{array}$ & $\begin{array}{l}\text { Proving an answer related to } \\
\text { human behaviour or treatment } \\
\text { practice rather than life sciences }\end{array}$ & 8 \\
\hline $\begin{array}{l}\text { Systemic / mental } \\
\text { model misconceptions }\end{array}$ & $\begin{array}{l}\text { Explaining antibiotic resistance } \\
\text { e.g. with concepts of immunology }\end{array}$ & 13 \\
\hline $\begin{array}{l}\text { Factual } \\
\text { misconceptions }\end{array}$ & $\begin{array}{l}\text { Use of erroneous concepts, such } \\
\text { as considering probiotics as a } \\
\text { synonym for lactic acid bacteria }\end{array}$ & 7 \\
\hline False beliefs & $\begin{array}{l}\text { Use of erroneous words such as } \\
\text { "flora" when referring to } \\
\text { microbiota }\end{array}$ & 7 \\
\hline
\end{tabular}

\section{Prior knowledge related to course success and study progress}

Students had completed an average of 41.2 study credits $(\mathrm{SD}=11.8 ; \min =4.0 ; \max =67.0)$ by the end of the second semester in 2019. When comparing students' success in MCQs with their study progress, it became apparent that MCQ scores in the pre-test correlated significantly with the study progress $(r=0.345 ; p<0.000)$, course grade $(r=0.424 ; p<0.000)$ and case task scores $(r=0.218$; $p=0.029)$. This means that students who had received higher scores in the pre-test, also received higher scores in the case task and succeeded better in the introductory course in general. Success in the pre-test MCQs also predicted faster study progress during the first study year. 


\section{Discussion}

The aim of this study was to investigate first-year pharmacy students' initial conceptual understanding related to the basics of biosciences utilising MCQs and a patient case task and study, and how this is linked to course success and general study progress during the first academic year. The results of the study revealed relatively serious gaps and misconceptions in students' conceptual understanding concerning elementary knowledge. This is a worrying result, because challenges in conceptual understanding may have serious consequences later in their university study (Södervik et al., 2017 Södervik, Mikkilä-Erdmann \& Chi, 2019). In the pharmacy context, a lack of knowledge on basic concepts of biomolecules or cellular processes may have a detrimental impact on understanding pharmacodynamics and pharmacokinetics later.

However, it seems to be possible to predict later study success and progress with a relatively light prior knowledge test. This would enable identifying 'at risk' students in the early stages of their university study in order to provide them with extra support. However, to gain deeper understanding of students' conceptions and the dynamics of misconceptions, problem-solving tasks such as case tasks need to be utilised.

The misconceptions identified in this study reflect a wide spectrum of flaws in the scientific mindset of students, ranging from the use of outdated terminology (false beliefs) and seemingly harmless wrong definitions for terms (factual misconceptions) to systems' and ontological level misunderstandings. However, the seemingly harmless misuse of terms such as using "probiotics" and "lactic acid bacteria" interchangeably may arise from severe misconceptions which could hinder learning in later years. Not always registered as a drug, the widely accepted definition of probiotics sets criteria on quality and efficacy of a microbial strain and links these properties to a certain dose, thus making a clear distinction from any lactic acid bacteria strain (Sanders, 2008). This distinction is linked with concepts of evidence-based medicine and also to the nature of drugs as meeting a certain set of criteria in terms of efficacy, safety and pharmaceutical quality, both of which are essential elements in the pharmacy discipline. Misconceptions or alternative conceptions found in categories of false beliefs and factual misconceptions may be resolved through belief revision by increasing the students' knowledge on terminology of phenomena.

Misconceptions at the mental model level were most common and they indicate that several students had a poor understanding of the phenomenon of antibiotic resistance. The mental model level misconceptions found in this study, explaining antibiotic resistance as stemming from an immunological response of a human body or a bacterium towards the antibiotic, reflects a robust mixing of fundamental life science concepts and is likely to affect the ability of a student to understand the spread of antibiotic resistance or measures taken to prevent it. The naïve conceptions not distinguishing life science-related phenomena from clinical practice (ontological misconception) can be considered to stem from a lack of understanding of the nature of pharmacy as a multidisciplinary subject connecting the two aspects of drug action and use. Conceptual change at that level requires categorical shift (Chi, 2008), which will require teachers to speak out about the basis of their own professional thinking.

Previous studies have shown that lay people have misconceptions related to using antibiotics safely. Lack of adequate knowledge about antibiotics has been widely outlined as being a major reason for inappropriate use of antibiotics, which includes failure to complete treatment, skipping doses, re-use of leftover medicines and overuse of antibiotics (Kim et al., 2011, Ling Oh et al., 2011, You et al., 2008). On the other hand, pharmacist-initiated and easily-administered educational intervention supported lay persons' understanding effectively (Shehadeh, Suaifan, \& Hammad, 2016). Thus, it is vital that pharmacists are capable of supporting customers' understanding related to appropriate use of antibiotics in patient encounters, which requires pharmacists to have a deep understanding of natural science phenomena.

\section{Limitations of the study}

This study reveals important aspects related to learning pharmacy during the first year of study at university. However, the following aspects need to be considered when generalising the results outlined in this paper. At first, ten MCQs were used to measure students' level of prior knowledge. Although even these ten MCQs seemed to predict future success, it would be important to repeat the study with a larger sample and in other contexts.

Additionally, according to Finnish national core curriculum, all the participants of this study had accomplished at least two mandatory biology courses at high school. However, in high school, students have an option to study compulsory, advancing courses of biology and this aspect was not controlled in the study. However, all the participants of this study had accomplished the entrance examination in the same year, 2018, that was based on Finnish national core curriculum and hence, students can be assumed to enter the study programme having a relatively similar study background in biology.

Lastly, only one type of case task was utilised in this study. The choice of a case topic on antibiotic resistance was based on the idea that understanding it is crucial for pharmacy students from their first encounters with patients. However, further studies with different topics should be undertaken to investigate which types of misconception would arise related to other central topics. Lastly, it would be important to follow these participants during their university studies to investigate how students' understanding develops.

\section{Pedagogical contributions}

This study showed that the level of prior knowledge predicts study success during the first academic year. In 
addition, the study revealed that pharmacy students have different level misconceptions and a basic lack of knowledge when they start university. According to previous studies, challenges in conceptual understanding may have serious consequences in later years (Södervik, Mikkilä-Erdmann \& Chi, 2019) and therefore, educators should be aware of the heterogeneity of students concerning their levels of prior knowledge and design their instruction accordingly. The challenge is that higher education teachers are often not aware of students' typical misconceptions, which may hinder their learning, or teachers might not even necessarily consider instruction as an efficient way to support students' learning (Michael et al., 1999 Michael, 2002). Additionally, higher education teachers' own reasoning processes may be so automated that it is difficult for them to model their own expert-level reasoning processes and to understand that new students enter their programmes with possible misconceptions.

To develop systemic, expert-level understanding takes time and requires many conceptual change transformations among novices. Most of these changes do not occur naturally but require systematic studying by students and support from the higher education learning environment. Therefore, becoming aware of the level and quality of students' prior knowledge as well as typical misconceptions, is crucial. This study indicates that even a very short prior knowledge test can predict students' study success during the first year. This is an important notion that should have implications in instructional practices in pharmacy education. However, short multiple-choice questionnaires may leave certain aspects unrevealed, which is why utilising case tasks requiring problem-solving skills, which became evident when inspecting the results of the case task. Further, according to current understanding of the development of expertise, instruction at universities should be adapted to the actual knowledge organisation of the student (Lubarsky et al., 2015), which is why using case tasks should start in the early phases of university studies. The need to develop new materials and new teaching and learning practices in pharmacy classrooms is therefore critical to advance pharmacy education.

\section{Conclusions}

Pharmacy students are a highly select group of talented and motivated students; in 2018 , only about $12.5 \%$ of applicants were accepted. However, it is relatively common even for pharmacy students to start university with different level misconceptions related to scientific phenomena central to their discipline. Although this study was accomplished in the context of pharmacy teaching and learning, the findings contribute to the larger-scale discussion about the domain-specific conceptual understanding in higher education. It seems that even in higher education, students struggle with inadequate prior knowledge and a range of misconceptions. However, detection of these challenges seems to be possible at the very beginning, which enables providing early support to students at risk of delays in their academic progress. These findings should have implications in organising the instruction at university in general, in order to support the development of expertise in higher education.

\section{Acknowledgements}

We thank the students, who participated in this study. We also thank University of Helsinki for supporting this research paper via the project of Cultivating Expertise in Learning of Life Sciences, CELLS (Research Funds of the University of Helsinki, HY/716/05.01.07/2018).

\section{References}

Barak, J., Sheva, B., Gorodetsky, M., \& Gurion, B. (1999). As "process" as it can get: students" understanding of biological processes. International Journal of Science Education, 21(12), 1281-1292. doi: 10.1080/095006999290075

Boshuizen, H.P.A., \& Schmidt, H.G. (2008). The development of clinical reasoning expertise: Implications for teaching. In Clinical reasoning in the health professions, (eds. J. Higgs, M. Jones, S. Loftus, \& N. Christensen), Oxford: Butterworth-Heinemann/Elsevier, 3rd ed., pp. 57-65.

Boshuizen, H.P.A., van de Wiel, M.W.J., \& Schmidt, H.G. (2012). What and how advanced medical students learn from reasoning through multiple cases. Instructional Science, 40(5), 755-768.

Bransford, J.D., Brown, A.L., \& Cocking, R.R. (2000). How people learn: Brain, Mind, Experience and School: Expanded Edition of Sciences. Washington, D.C: National Academy Press.

Branstädter, K., Harms, U., \& Großschedl, J. (2012). Assessing System Thinking Through Different ConceptMapping Practices. International Journal of Science Education, 34(14), 2147-2170. doi: 10.1080/09500693. 2012.716549

Broughton, S.E., Sinatra, G.M., \& Nussbaum E.M. (2013). "Pluto Has Been a Planet My Whole Life!" Emotions, Attitudes, and Conceptual Change in Elementary Students Learning about Pluto's Reclassification. Research in Science Education, 43(2), 529-550. doi: 10.1007/s11165-011-9274-X

Carey, S. (1985). Conceptual change in childhood. Cambridge, MA: MIT Press

Carey, S. (2000). Science Education as Conceptual Change. Journal of Applied Developmental Psychology, 21(1), 13-19. doi: 10.1016/S0193-3973(99)00046-5

Chi, M.T.H. (1992). Conceptual change within and across ontological categories: examples from learning and discovery in science. In Cognitive models of science: Minnesota studies in the philosophy of science, (ed. R. Giere), Minneapolis, MN: University of Minnesota Press, pp. 129-186 
Chi, M.T.H. (1997). Quantifying qualitative analyses of verbal data: A practical guide. The Journal of the Learning Sciences, 6(3), 271-315. doi: 10.1207/ s15327809j1s0603_1

Chi, M.T.H. (2005). Commonsense conceptions of emergent processes: Why some misconceptions are robust. Journal of the Learning Sciences, 14(2), 161199. doi: 10.1207/s15327809j1s1402_1

Chi, M.T.H. (2008). Three types of conceptual change: Belief revision, mental model transformation, and categorical shift. In International handbook of research on conceptual change, (ed. S. Vosniadou), New York: Routledge, pp. 61-82

Chi, M.T.H. (2013). Two kinds and four sub-types of misconceived knowledge, ways to change it, and the learning outcomes. In International handbook of research on conceptual change, (ed. S. Vosniadou), New York: Routledge, 2nd ed., pp. 49-70

Chi, M.T.H., Chiu, M.-H., \& deLeeuw, N. (1991). Learning in a non-physical science domain: The human circulatory system. Pittsburgh, PA: Pittsburgh University Learning Research and Development Center

Chi, M.T.H., \& Roscoe, R.D. (2002). The process and challenges of conceptual change. In Reconsidering conceptual change: Issues in theory and practice, (eds. M. Limón \& L. Mason), Dordrecht, Netherlands: Kluwer Academic Publishers, pp. 3-27

Chinn, C.A., \& Brewer, W.F. (1993). The role of anomalous data in knowledge acquisition: a theoretical framework and implications for science instruction. Review of Educational Research, 63(1), 1-49. doi: 10.3102/00346543063001001

Diakidoy, I.A.N., Kendeou, P., \& Ioannides, C. (2003). Reading about energy: The effects of text structure in science learning and conceptual change. Contemporary Educational Psychology, 28(3), 335-356.doi: 10.1016/ S0361-476X(02)00039-5

diSessa, A.A. (1993). Toward an Epistemology of Physics. Cognition and Instruction, 10(2/3), 105-225. doi: 10.1080/07370008.1985.9649008

Duit, R., \& Treagust, D.F. (2003). Conceptual change: A powerful framework for improving science teaching and learning. International Journal of Science Education, 25(6), 671-688. doi: 10.1080/09500690305016

Flaig, M., Simonsmeier, B.A., Mayer, A.-K., Rosman, T., Gorges, J., \& Schneider, M. (2018). Conceptual change and knowledge integration as learning processes in higher education: A latent transition analysis. Learning and Individual Differences, 62, 49-61. doi: 10.1016/ j.lindif.2017.12.008

Hsieh, H.-F., \& Shannon, S.E. (2005). Three approaches to qualitative content analysis. Qualitative Health Research, 15(9), 1277-1288. doi: 10.1177/1049732 305276687

Kim, S.S., Moon, S. \& Kim, E.J. (2011). Public Knowledge and Attitudes Regarding Antibiotic Use in South Korea. Journal of Korean Academy of Nursing, 41(6), 742-749. doi: 10.4040/jkan.2011.41.6.742.
Limón, M. (2001). On the cognitive conflict as an instructional strategy for conceptual change: a critical appraisal. Learning and Instruction, 11(4-5), 357-380. doi: 10.1016/S0959-4752(00)00037-2

Limón, M., \& Mason, L. (2002). Prologue. In Reconsidering conceptual change: Issues in theory and practice, (eds. M. Limón \& L. Mason), Dordrecht, Netherlands: Kluwer Academic Publishers, pp. Xv-Xx

Lubarsky, S., Dory, V., Audétat, M.C., Custers, E., \& Charlin, B. (2015). Using script theory to cultivate illness script formation and clinical reasoning in health professions education. Canadian Medical Education Journal, 6(2), e61-e70

Mason, L. (2001). Responses to anomalous data and theory change. Learning and Instruction, 11(6), 453-483, doi: 10.1016/S0959-4752(00)00042-6

Mayr, E. (1997). This is biology: The science of the living world. Cambridge, MA: Belknap Press

Michael, J.A., Richardson, D., Rovick, A., Modell, H., Bruce, D., Horwitz, B., Hudson, M., Silverthorn, D., Whitescarver, S., \& Williams, S. (1999). Undergraduate students' misconceptions about respiratory physiology. Advances in Physiology Education, 277(6/2), 127-135. doi: 10.1152/advances.1999.277.6.S127

Michael, J.A., Wenderoth, M.P., Modell, H.I., Cliff, W., Horwitz, B., McHale, P., Richardson, D., Silverthorn, D., Williams, S., \& Whitescarver, S. (2002). Undergraduates' understanding of cardiovascular phenomena. Advances in Physiology Education, 26(1-4), 72-84. doi: 10.1152/ advan.00002.2002

Oh, A.L., Hassali, M.A., Al-Haddad, M.S., Sulaiman, S.A.S., Shafie, A.A., \& Awaisu, A. (2011). Public knowledge and attitudes towards antibiotic usage: a cross-sectional study among the general public in the state of Penang, Malaysia. Journal of Infection in Developing Countries, 5(5), 338-347. doi: 10.3855/jidc. 1502

Plate, R. (2010). Assessing individuals' understanding of nonlinear causal structures in complex systems. System Dynamics Review, 26(1), 19-33. doi: 10.1002/sdr.432

Posner, G.J., Strike, K.A., Hewson, P.W., \& Gertzog, W.A. (1982). Accommodation of a scientific conception: Toward a theory of conceptual change. Science Education, 66(2), 211-227. doi: 10.1002/sce.3730660207

Sanders, M.E. (2008). Probiotics: Definition, Sources, Selection, and Uses. Clinical Infectious Diseases, 46(2), 58-61, doi: 10.1086/523341

Shehadeha, M.B., Suaifana, G.A.R.Y., \& Hammad, E.A. (2016). Active educational intervention as a tool to improve safe and appropriate use of antibiotics. Saudi Pharmaceutical Journal, 24(5), 611-615. doi: 10.1016/ j.jsps.2015.03.025

Sinatra, G., \& Mason, L. (2013). Beyond knowledge: Learner characteristics influencing conceptual change. In International handbook on conceptual change research, (ed. S. Vosniadou), 2nd ed., New York: Routledge, pp. 377-394 
Sinatra, G.M., \& Pintrich, P.R. (2003). Intentional Conceptual Change. Mahwah, NJ: Lawrence Erlbaum Associates, Inc.

Södervik, I., Vilppu, H., Österholm, E., \& MikkiläErdmann, M. (2017). Medical Students' Biomedical and Clinical Knowledge: Combining Longitudinal Design, Eye Tracking and Comparison with Residents' Performance. Learning and Instruction, 52, (139-147). doi: 10.1016/j.learninstruc.2017.06.002

Södervik, I., Mikkilä-Erdmann, M., \& Chi, T.H. (2019). Conceptual change challenges in medicine during professional development. International Journal of Educational Research, 98, 159-170. doi: 10.1016/j.ijer. 2019.07.003

Treagust, D.T., \& Duit, R. (2008). Conceptual change: A discussion of theoretical, methodological and practical challenges for science education. Cultural Studies of Science Education, 3, 297-328. doi: 10.1007/ s11422-008-9090-4

Verhoeff, R.P., Waarlo, A.J., \& Boersma, K.T. (2008). Systems modelling and the development of coherent understanding of cell biology. International Journal Science Education, 30(4), 543-568. doi: 10.1080/ 09500690701237780

Vosniadou, S. (1994). Capturing and modeling the process of conceptual change. Learning and Instruction, 4(1), 45-69. doi: 10.1016/0959-4752(94)90018-3

Vosniadou, S. (2013). Conceptual change in learning and instruction - The Framework Theory Approach. In International handbook on conceptual change research, (ed. S. Vosniadou), New York: Routledge, 2nd ed., pp. 11-30

Vosniadou, S. \& Skopeliti, I. (2005). Developmental shifts in children's categorization of the earth. In Proceedings of the XXVII Annual Conference of the Cognitive Science Society, (eds. B. G. Bara, L. Barsalou \& M. Bucciarelli), Mahwah, NJ: Lawrence Erlbaum Associates, pp. 2325-2330

WHO [World Health Organisation]. (2015). Global action plan on antimicrobial resistance (online). Available at: https://apps.who.int/iris/bitstream/handle/ $\underline{10665 / 193736 / 9789241509763 \text { eng.pdf?sequence }=1}$. Accessed 8th May, 2019

You, J.H.S., Yau, B., Choi, K.C., Chau, C.T.S., Huang, Q.R., \& Lee, S.S. (2008). Public Knowledge, Attitudes and Behavior on Antibiotic Use: A Telephone Survey in Hong Kong. Infection, 36(2), 153-157. doi: 10.1007/ s15010-007-7214-5 